\title{
Linkage stratification and mutation analysis at the parkin locus identifies mutation positive Parkinson's disease families
}

\author{
W C Nichols, N Pankratz, S K Uniacke, M W Pauciulo, C Halter, A Rudolph, \\ P M Conneally, T Foroud, and the Parkinson Study Group
}

$\mathrm{P}$ arkinson's disease (PD) is one of the most common neurological disorders in humans with an overall prevalence of 1:1000 with the incidence increasing to as high as $3.4 \%$ among people aged 75 years. ${ }^{12}$ The clinical phenotype includes resting tremor, muscular rigidity, bradykinesia, and postural instability. The signs and symptoms of the disease are the consequence of a striatal deficiency of dopamine resulting from neuronal death in the substantia nigra. It is characterised by the presence of the Lewy body, an intracytoplasmic inclusion body found in many brain regions which is not entirely specific to, but is a highly sensitive marker for, Parkinson's disease.

The pathogenesis of idiopathic Parkinson's disease is unknown. For the overwhelming majority of PD patients, the disease has previously been thought to occur sporadically. However, there is increasing evidence of a genetic contribution to the disorder. ${ }^{3}$ Recently, two studies have investigated familial aggregation of PD using large, population based, casecontrol studies. Elbaz et $a l^{4}$ reported an odds ratio of 3.2 for the presence of PD in first degree relatives (parents and sibs) of 175 cases as compared to 481 controls. Analyses stratified by age showed this aggregation to be stronger for younger PD patients. Familial aggregation of PD in Iceland was studied using a cohort of 772 cases, with 560 having onset of disease at $>50$ years of age. ${ }^{5}$ In this study, the odds ratio for PD was 6.7 for sibs and 3.2 for offspring of affected subjects. These studies are consistent with others reporting the risk to be anywhere from two to 14 times higher for first degree relatives as compared to the risk in members of unaffected families. ${ }^{6-9}$

Genetic linkage analyses in families with either autosomal dominant forms of PD or with an autosomal recessive, juvenile form of the disorder have resulted in the identification of at least two Parkinson disease genes as well as potential linkage for several others. The first genetic evidence that some forms of PD might be caused by mutations in a single gene(s) occurred with the linkage of a large Italian kindred, in which pathologically confirmed PD was segregating in an autosomal dominant manner, to the PARKI locus on the long arm of chromosome 4 (4q21-q23). ${ }^{10}$ This linkage enabled the identification of $\alpha$-synuclein as the causative gene in this and other families with a similar form of the disease. ${ }^{11-13}$ However, as only two missense mutations have been identified in a very limited subset of PD patients and families, the $\alpha$-synuclein gene is not a major risk factor in familial Parkinson's disease. ${ }^{14-16}$ The ubiquitin carboxy-terminal hydrolase Ll $(U C H-L 1)$ gene has also been implicated in disease causation with the identification of a missense mutation in two PD patients of a German pedigree. ${ }^{17}$ Two additional genetic loci have been mapped in autosomal dominant Parkinson's disease, PARK3 on chromosome $2 \mathrm{pl}^{18}$ and PARK4 on chromosome 4p14-16.3. ${ }^{19}$ However, autosomal dominant forms of the disorder are rare and seem to account for only a small number of families.
Autosomal recessive, juvenile parkinsonism is a distinct clinical entity within familial Parkinson's disease originally described in Japanese patients. ${ }^{20}$ Linkage analysis in 13 Japanese families identified PARK2 on the long arm of chromosome 6 (6q25.2-27). ${ }^{21}$ Subsequent positional cloning efforts identified a novel gene, parkin, as the causative gene for autosomal recessive, juvenile parkinsonism..$^{22} \mathrm{~A}$ wide variety of parkin mutations have been identified in families with autosomal recessive parkinsonism and in sporadic cases of different ethnic origin. ${ }^{23-25}$ Two additional loci for the autosomal recessive form of the disorder, PARK6 and PARK7, were recently identified on chromosome $1 \mathrm{p} 35-\mathrm{p} 36^{26}$ and $1 \mathrm{p} 36,{ }^{27}$ respectively.

\section{MATERIAL AND METHODS}

In an effort to identify additional genetic factors contributing to Parkinson's disease, we have initiated the collection and analysis of a large panel of affected sib pairs. Families reporting at least two living sibs diagnosed or considered likely to be diagnosed with PD were ascertained through a variety of sources, including 52 US and Canadian centres participating in the Parkinson Study Group (PSG). All study participants completed a uniform clinical evaluation that consisted of parts II and III of the Unified Parkinson Disease Rating Scale (UPDRS).$^{28}$ In addition, a diagnostic checklist was developed based on the results of clinicopathological studies of parkinsonism so as to reach an acceptable degree of diagnostic specificity and sensitivity. ${ }^{29}{ }^{30}$ All study participants were then classified as either verified PD (VPD) or non-verified PD (NVPD), based on the results of the diagnostic checklist. The sample to date consists of 230 participants with VPD and 64 participants classified as NVPD giving a total of 162 sib pairs from 148 families and 94 affected sib pairs classified as verified PD from 86 families. Our sample consists of $95 \%$ whites and $5 \%$ Hispanics with an average age of onset of 60.4 years. Peripheral blood was obtained from all subjects after appropriate written informed consent approved by each individual institution's IRB. DNA was prepared using standard methods. ${ }^{31}$

As mutations in parkin are the most common inherited defect identified in PD to date, our initial efforts were focused on looking for evidence of linkage to the parkin locus. DNA samples from all 162 sib pairs were genotyped using 21 chromosome 6 dinucleotide repeats which are part of the ABI Prism Linkage Mapping Set (Applied Biosystems, Foster City, CA), including D6S305 located within intron 7 of the parkin gene. Briefly, 30 ng of genomic DNA was PCR amplified using each individual marker in a $10 \mu \mathrm{l}$ reaction. After PCR, the PCR products were pooled using equal amounts of each PCR reaction. One $\mu \mathrm{l}$ of this multiplexed mix was added to $10 \mu \mathrm{l}$ formamide containing the GeneScan-400HD ROX size standard (Applied Biosystems, Foster City, CA). Genotypes were determined using the ABI 3700 DNA Analyzer (Applied 
Table 1 Parkin mutations identified in 16 Parkinson disease families

\begin{tabular}{|c|c|c|c|c|c|c|c|c|c|c|}
\hline Family & $\begin{array}{l}\text { No } \\
\text { affected }\end{array}$ & Lod score & Age of onset & Mutation 1 & Exon & AA change & Zygosity & Mutation 2 & Exon & AA change \\
\hline 33007 & 2 & 0.4031 & 28,44 & Duplication & 7 & & Hetero & & & \\
\hline 05007 & 4 & 0.7164 & $45,45,45,45$ & Deletion & 3,4 & Gln57fs $(+35 \mathrm{aa}) \dagger$ & Homo & & & \\
\hline 15007 & 2 & 0.5376 & 38,38 & c. $337-377 \mathrm{del}^{*}$ & 3 & Leu $112 \mathrm{fs}$ (+50 aa) & & Deletion & $4,5,6$ & \\
\hline 47007 & 2 & 0.1719 & 50,51 & Deletion & 8 & & Hetero & & & \\
\hline 68007 & 4 & 1.4682 & $25,31,50,50$ & Deletion & 3 & $G \ln 57 f_{s}(+328 \mathrm{ad})$ & & Deletion & $2,3,4$ & \\
\hline 79007 & 2 & 0.3599 & 24,30 & Deletion & 3,4 & Gln57fs (+35 aa) & Homo & & & \\
\hline 71107 & 2 & 0.4999 & 32,54 & c. $154 \mathrm{del} \mathrm{A}$ & 2 & Arg50fs (+28 aa) & Homo & & & \\
\hline 73107 & 2 & 0.3197 & 34,36 & C823T & 7 & Arg275Trp & & Deletion & 3,4 & \\
\hline 93107 & 2 & 0.1424 & 48,50 & Duplication & 8 & & Hetero & & & \\
\hline 74107 & 2 & 0.547 & 47,62 & Duplication & 5 & & Hetero & & & \\
\hline 56107 & 2 & 0.5147 & 45,72 & Duplication & 3 & & Hetero & & & \\
\hline 79107 & 3 & 0.9522 & $38,38,38$ & А633T & 6 & Lys211 Asn & & Duplication & 2,3 & \\
\hline 93207 & 2 & 0.5538 & 35,45 & C823T & 7 & Árg275Trp & Hetero & & & \\
\hline 26207 & 2 & 0.5348 & 59,65 & Duplication & 8 & & Hetero & & & \\
\hline 60307 & 2 & 0.4792 & 22,38 & C823T & 7 & Arg275Trp & & C1310T & 12 & Pro437Leu \\
\hline 01307 & 2 & 0.3999 & 35,44 & Deletion & 6 & & & Deletion & 8,9 & \\
\hline
\end{tabular}

*Nucleotides are numbered according to GenBank Accession AB009973 with the A of the initiator ATG numbered as +1 .

†Frameshifts are denoted by the amino acid and its number at which the frameshift occurs as recommended by Dunnen and Antonarakis. ${ }^{38}$

Biosystems, Foster City, CA) and GeneScan 3.5, Genotyper 3.6, and GeneMapper 1.1 software. All genotypic data were checked for Mendelian inheritance of marker alleles with the program Pedcheck. ${ }^{32}$ The marker genotypic data, including genotypic data from other parts of the genome, were used to verify the full sib relationships among the subjects using the computer program RELATIVE. ${ }^{33}$

Observed allele frequencies in the subjects genotyped for the genome screen were used. Marker order and map positions were obtained from the Marshfield Medical Research Foundation (http://research.marshfieldclinic.org/genetics/). Multipoint affected sib pair linkage analysis was performed using the program Mapmaker/Sibs and included dominance variance in the model. ${ }^{34}$ Lod scores were computed at $1 \mathrm{cM}$ intervals along chromosome 6, using all possible sib pairs formed from families with more than two affected sibs. The parkin gene was previously reported to result in autosomal recessive PD; therefore, parametric linkage analysis was also performed using the computer program Allegro $^{35}$ and an autosomal recessive, fully penetrant disease model with the disease allele having a frequency of 0.01. Analyses were performed using two models of affection: (1) including both verified and non-verified PD as affected, and (2) including only verified $\mathrm{PD}$ as affected.

Initial analyses of chromosome 6 using all available sib pairs resulted in a maximum lod score of 0.7 at marker D6S305. The highest peak in the region was $30 \mathrm{cM}$ centromeric at D6S292 $(\operatorname{lod}=1.9)$. When analyses were restricted to only those sib pairs with VPD, the maximum lod score at the marker D6S305 in the parkin gene was reduced to 0.2 , though the highest peak in the region remained at D6S292 (lod=1.2). Parametric linkage analyses performed using all available subjects also excluded linkage to this region using an autosomal recessive ( $\operatorname{lod}=-68.5)$ mode of inheritance. When affection was limited to only those subjects with verified $\mathrm{PD}$, the region was still excluded $($ lod $=-38.4)$. These parametric linkage results were evaluated for each family, and 56 of the 148 families analysed had positive lod scores at D6S305, ranging from 0.0111 to 1.667. The ethnicity of these 56 families is $90 \%$ white and $10 \%$ Hispanic.

The positive lod scores at the parkin locus in this subset of 56 families prompted analysis of the parkin gene in the 113 affected subjects from these 56 families using both direct sequencing and fluorescent dosage analysis. By BLAST similarity searching of GenBank (http:// www.ncbi.nlm.nih.gov/) and Celera (http://www.celera.com/) databases using a full length parkin cDNA sequence (GenBank accession number AB009973), the intron/exon boundaries of the gene were determined, which in turn enabled the design of intronic PCR primers (sequences available upon request). For direct sequence analysis, all 12 exons of the parkin gene were PCR amplified for all 113 subjects. The resulting PCR products were purified using the QIAquick 96 PCR purification kit (QIAGEN, Santa Clara, CA) and sequenced on an ABI 3700 DNA analyser using the Applied Biosystems BigDye Terminator version 2.0 kit. We confirmed segregation of the mutations within families, and excluded the presence of the mutations in a panel of 182 normal chromosomes, by PCR amplification of the relevant exon followed by either mutation specific restriction fragment length polymorphism (RFLP) analysis or direct sequencing.

Fluorescent dosage PCR was performed as described by Yau et al. ${ }^{36}$ Briefly, $125 \mathrm{ng}$ of genomic DNA was PCR amplified using a fluorescently labelled forward PCR primer. Multiplex PCR reactions were performed for exons 2-12 of the parkin gene in two different groups with group 1 containing exons $4,6,7,8$, 9 , and 12 and group 2 containing exons 2, 3, 5, 10, and 11 . PCR products were electrophoresed on an ABI 377 DNA Analyzer. Data were analysed using GeneScan and Genotyper software to produce electropherograms showing the size in base pairs of the peaks and areas under the peaks representing the amount of PCR product present. To determine gene dosage for each exon, samples were compared to each other, as well as to control samples, to obtain the dosage quotients. Each sample was repeated three times. Any individual exon sample giving an ambiguous or uninterpretable result was repeated an additional three times.

\section{RESULTS}

Results of the direct sequence and fluorescent dosage analysis are shown in table 1 and fig 1 . Seventeen different parkin mutations were identified in 16 of 56 families analysed. Five of the mutations were detected more than once with the missense mutation Arg275Trp (three families) and the exon 8 duplication ( 3 families) accounting for $\sim 40 \%$ of mutation positive families. It is not known whether these recurrent mutations are the result of a shared haplotype or represent independent mutational events. Three (16\%) of the mutation positive families are of Hispanic origin; however, none of them carries the same mutation. The remaining 12 mutations were each detected in a single family. Three of the 17 mutations are missense mutations resulting in single amino acid substitutions in the parkin peptide. The remaining 14 are either deletions ranging in size from one base (154delA) up to entire exons or duplications of entire exons. All of the deletion and duplication mutations would predict a frameshift, except for the exon 3 and 4 deletion that predicts an in frame deletion of 


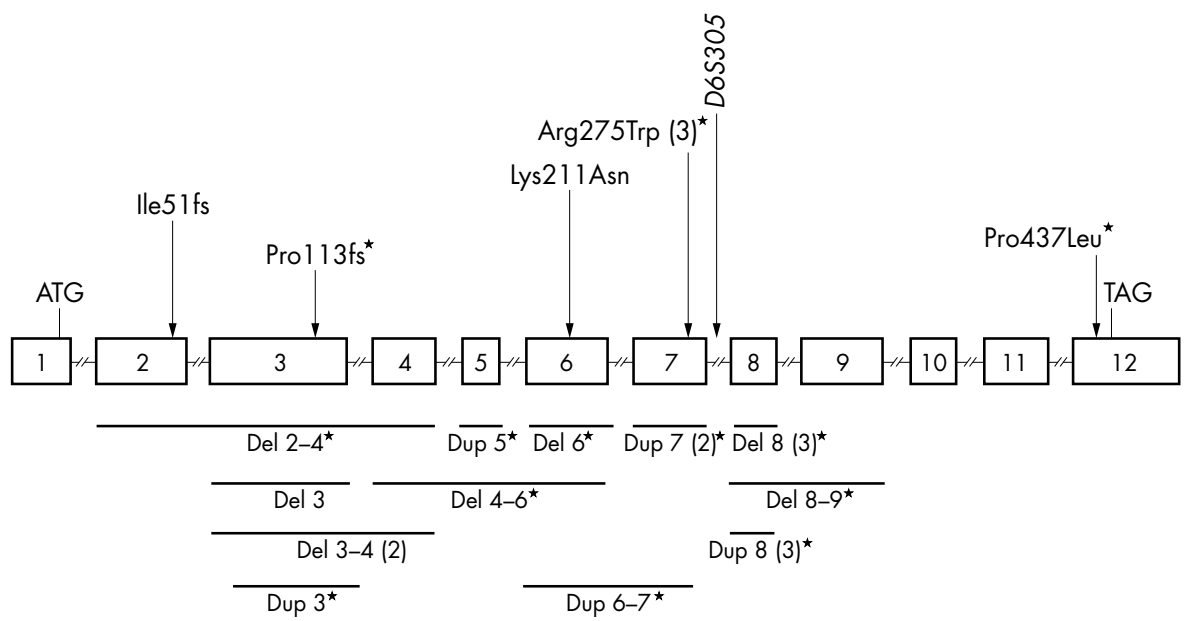

Figure 1 Location of identified parkin mutations within the parkin gene. The 12 exons of the parkin gene are depicted as rectangles numbered 1-12. Locations of the initiator ATG and terminator TAG are as shown. Missense and small insertion/deletion frameshift mutations are depicted above the gene while mutations resulting in deletions/duplications of entire exons are indicated below the gene. All mutations were identified in a single family except those with a number in parentheses beside the mutation. The number in parentheses indicates the number of families in which those mutations were identified. An asterisk indicates mutations that were detected as heterozygous changes.

amino acids 58-178 and the exon 5 duplication that predicts an in frame duplication of amino acids 179-206. Affected subjects were determined to be either homozygous or compound heterozygous in nine of the 16 families in which parkin mutations were detected (table 1). Mutations were only detected on one allele in affected subjects in the remaining seven families. Whether these patients are truly heterozygous or compound heterozygotes with the other allele carrying an undetected mutation remains to be determined. Our method of direct sequencing and fluorescent dosage would clearly miss any mutations that are not within the coding region, that is, those in the promoter or introns. Heterozygosity for parkin mutations in PD has been previously reported, and it has also been hypothesised that these subjects probably carry an undetected mutation on their other parkin allele. ${ }^{23} 24$

\section{DISCUSSION}

Of the 17 mutations identified in this study, 12 have been previously reported. ${ }^{23-25}{ }^{37}$ The five novel mutations reported here consist of one missense mutation, three exon duplications, and one exon deletion. While we have no evidence in our study whether the recurrent mutations represent common founders or independent mutational events, Periquet et $a l^{25}$ recently reported that haplotype analysis of 48 families carrying 14 distinct mutations indicated that some of the point mutations seem to arise from a common founder while the events involving whole exons occurred independently. The Arg275Trp mutation has now been identified in at least 12 unrelated families. ${ }^{23-25}$ An additional 116 affected subjects from 58 families who did not have positive parkin lod scores were screened by PCR and restriction endonuclease digestion for some of the mutations reported here as well as other previously reported mutations which were determined to change a restriction site. In this manner, two additional families were identified with mutations, one each with the 219-220insGT mutation previously reported by Abbas et $\mathrm{al}^{23}$ and the Gly430Asp mutation reported by Periquet et al. ${ }^{25}$ No additional mutations were detected in any other affected subjects/families. Subsequent analyses of only those families without identified parkin mutations resulted in lod scores $<0.1$ for this entire region of chromosome 6, suggesting that all families with mutations had been identified.

The approach we are taking to identify additional genetic loci shows the synergy of linkage stratification and direct sequencing to identify mutation positive families. Our initial analysis of either the full sample of 162 affected sib pairs or the subset of 94 sib pairs with verified PD yielded no evidence of linkage to the parkin region. However, stratification of the sample by families with suggestive evidence of allele sharing at, or linkage to, the parkin gene enabled the identification of 17 parkin mutations in 16 of $56(29 \%)$ families analysed. While all other reports have stratified samples based on age of onset of PD of 45 years or less for mutation detection, ${ }^{23}$ our strategy to analyse those families with evidence of positive lod scores at the parkin locus yielded the highest percentage of parkin mutations of any study to date. ${ }^{24}{ }^{37}$ The ages of onset of those affected subjects in whom parkin mutations were identified in this study ranged from 22-69 years. However, four of the 16 mutation positive families had ages of onset greater than 45 years for all affected subjects and would have thus been missed if we had used age of onset as our stratification criteria. As well, identification and removal of subjects with mutations in known genes from subsequent genome wide analyses will decrease the heterogeneity in this sample and probably increase the power of this sample of affected sib pairs to detect linkage to additional chromosomal regions harbouring genetic loci contributing to the susceptibility to PD.

\section{ACKNOWLEDGEMENTS}

This project was Supported by ROI NS37167. We thank the subjects for their participation in this research study. Support from NINDS NS37167 is gratefully acknowledged.

Participating Investigators and Coordinators: Drs J Carter, R Camicioli, J Wojcieszek, M Fernandez, J Hubble, A Rajput, A Rajput, M Panisset, T Mendis, D A Grimes, C Serrano Ramos, S Reich, R Hauser, J SanchezRamos, T Zesiewicz, R Pfeiffer, J Friedman, H Fernandez, C Shults, L Seeberger, C O'Brien, R Pahwa, L Elmer, D Jennings, K Marek, D Truong, M Pathak, R Rodnitzyk, R Kurlan, P Tuite, M Aminoff, K Marder, P Lewitt, W Koller, W Martin, J Jankovic, J Bertoni, S Factor, F Walker, U Jung Kang, M Stacy, D Simon, K Blindauer, B Manyam, A Nieves, M Velickovic, M F Gordon, M Leehey, P Gordon, J Rao, A Dalvi, B Racette, K Sethi, L Sudarsky, R Saunders Pullman, T Simuni, R Dewey, N Hermanowicz, A Feigin, V Calabresse, J Sutton, T Ajax, G D Podakalny, O Suchowersky, R Uitti, L Shulman.

\section{Authors' affiliations}

W C Nichols, S K Uniacke, M W Pauciulo, Division of Human

Genetics, Children's Hospital Medical Center, Cincinnati, OH, USA

N Pankratz, C Halter, P M Conneally, T Foroud, Department of

Medical and Molecular Genetics, Indiana University Medical Center Indianapolis, IN, USA 
A Rudolph, Department of Neurology, University of Rochester, Rochester, NY, USA

Correspondence to: Dr W C Nichols, Division of Human Genetics, Children's Hospital Medical Center, 3333 Burnet Avenue, Cincinnati, OH 45229, USA; bill.nichols@chmcc.org

\section{REFERENCES}

1 Riess O, Kuhn W, Kruger R. Genetic influence on the development of Parkinson's disease. J Neurol 2000;247(suppl 2):1169-74

2 de Rijk MC, Tzourio C, Breteler MM, Dartigues JF, Amaducci L, Lopez-Pousa S, Manubens-Bertran JM, Alperovitch A, Rocca WA. Prevalence of parkinsonism and Parkinson's disease in Europe: the EUROPARKINSON Collaborative Study. European Community Concerted Action on the Epidemiology of Parkinson's disease. J Neurol Neurosurg Psychiatry 1997;62:10-15.

3 Payami H, Zareparsi S. Genetic epidemiology of Parkinson's disease. J Geriatr Psychiatry Neurol 1998;11:98-106.

4 Elbaz A, Grigoletto F, Baldereschi M, Breteler MM, Manubens-Bertran JM, Lopez-Pousa S, Dartigues JF, Alperovitch A, Tzourio C, Rocca WA. Familial aggregation of Parkinson's disease: a population-based casecontrol study in Europe. EUROPARKINSON Study Group. Neurology 1999;52:1876-82.

5 Sveinbjornsdottir S, Hicks AA, Jonsson T, Petursson H, Gugmundsson G, Frigge ML, Kong A, Gulcher JR, Stefansson K. Familial aggregation of Parkinson's disease in Iceland. N Engl J Med 2000;343:1765-70.

6 Payami H, Larsen K, Bernard S, Nutt J. Increased risk of Parkinson's disease in parents and siblings of patients. Ann Neurol 1994:36:659-61.

7 Semchuk KM, Love EJ, Lee RG. Parkinson's disease: a test of the multifactorial etiologic hypothesis. Neurology 1993;43: $1173-80$.

8 Marder K, Tang MX, Mejia H, Alfaro B, Cote L, Louis E, Groves J, Mayeux R. Risk of Parkinson's disease among first-degree relatives: a community-based study. Neurology 1996;47:155-60.

9 Zareparsi S, Taylor TD, Harris EL, Payami H. Segregation analysis of Parkinson disease. Am J Med Genet 1998;80:410-17.

10 Polymeropoulos MH, Higgins JJ, Golbe LI, Johnson WG, Ide SE, Di lorio G, Sanges G, Stenroos ES, Pho LT, Schaffer AA, Lazzarini AM, Nussbaum RL, Duvoisin RC. Mapping of a gene for Parkinson's disease to chromosome 4q21-q23. Science 1996;274:1197-9.

11 Polymeropoulos MH, Lavedan C, Leroy E, Ide SE, Dehejia A, Dutra A, Pike B, Root H, Rubenstein J, Boyer R, Stenroos ES, Chandrasekharappa S, Athanassiadou A, Papapetropoulos T, Johnson WG, Lazzarini AM, Duvoisin RC, Di lorio G, Golbe LI, Nussbaum RL. Mutation in the alpha-synuclein gene identified in families with Parkinson's disease. Science 1997;276:2045-7.

12 Kruger R, Kuhn W, Muller T, Woitalla D, Graeber M, Kosel S, Przuntek $\mathrm{H}$, Epplen JT, Schols L, Riess O. Ala30Pro mutation in the gene encoding alpha-synuclein in Parkinson's disease. Nat Genet 1998;18:106-8.

13 Munoz E, Oliva R, Obach V, Marti M, Pastor P, Ballesta F, Tolosa E. Identification of Spanish familial Parkinson's disease and screening for the Ala53Thr mutation of the alpha-synuclein gene in early onset patients. Neurosci Lett 1997;235:57-60.

14 Scott WK, Yamaoka LH, Stajich JM, Scott BL, Vance JM, Roses AD, Pericak-Vance MA, Watts RL, Nance M, Hubble J, Koller W, Stern MB, Colcher A, Allen FH Jr, Hiner BC, Jankovic J, Ondo W, Laing NG, Mastaglia F, Goetz C, Pappert E, Small GW, Masterman D, Haines JL, Davies TL. The alpha-synuclein gene is not a major risk factor in familial Parkinson disease. Neurogenetics 1999:2:191-2.

15 Chan $\mathbf{P}$, Tanner CM, Jiang X, Langston JW. Failure to find the alpha-synuclein gene missense mutation (G209A) in 100 patients with younger onset Parkinson's disease. Neurology 1998;50:513-14.

16 Farrer M, Wavrant-De Vrieze F, Crook R, Boles L, Perez-Tur J, Hardy J, Johnson WG, Steele J, Maraganore D, Gwinn K, Lynch T. Low frequency of alpha-synuclein mutations in familial Parkinson's disease. Ann Neurol 1998;43:394-7.

17 Leroy E, Boyer R, Auburger G, Leube B, Ulm G, Mezey E, Harta G, Brownstein M, Jonnalagada S, Chernova T, Dehejia A, Lavedan $C$ Gasser T, Steinbach PJ, Wilkinson KD, Polymeropoulos MH. The ubiquitin pathway in Parkinson's disease. Nature 1998:395:451-2.

18 Gasser T, Muller-Myhsok B, Wszolek ZK, Oehlmann R, Calne DB, Bonifati V, Bereznai B, Fabrizio E, Vieregge P, Horstmann RD. A susceptibility locus for Parkinson's disease maps to chromosome $2 \mathrm{p} 13$. Nat Genet 1998;18:262-5.

19 Farrer M, Gwinn-Hardy K, Muenter M, DeVrieze FW, Crook R Perez-Tur J, Lincoln S, Maraganore D, Adler C, Newman S, MacElwee K, McCarthy P, Miller C, Waters C, Hardy J. A chromosome 4p haplotype segregating with Parkinson's disease and postural tremor. Hum Mol Genet 1999;8:81-5.
20 Yamamura Y, Sobue I, Ando K, lida M, Yanagi T. Paralysis agitans of early onset with marked diurnal fluctuation of symptoms. Neurology 1973;23:239-44.

21 Matsumine $\mathbf{H}$, Saito $M$, Shimoda-Matsubayashi $\mathrm{S}$, Tanaka $\mathrm{H}$, Ishikawa A, Nakagawa-Hattori Y, Yokochi M, Kobayashi T, Igarashi S, Takano H Sanpei K, Koike R, Mori H, Kondo T, Mizutani Y, Schaffer AA, Yamamura Y, Nakamura S, Kuzuhara S, Tsuji S, Mizuno Y. Localization of a gene for an autosomal recessive form of juvenile Parkinsonism to chromosome 6q25.2-27. Am J Hum Genet 1997;60:588-96.

22 Kitada T, Asakawa S, Hattori N, Matsumine H, Yamamura Y, Minoshima S, Yokochi M, Mizuno Y, Shimizu N. Mutations in the parkin gene cause autosomal recessive juvenile parkinsonism. Nature 1998;392:605-8

23 Abbas N, Lucking CB, Ricard S, Durr A, Bonifati V, De Michele G, Bouley S, Vaughan JR, Gasser T, Marconi R, Broussolle E, Brefel-Courbon C, Harhangi BS, Oostra BA, Fabrizio E, Bohme GA, Pradier L, Wood NW, Filla A, Meco G, Denefle P, Agid Y, Brice A. A wide variety of mutations in the parkin gene are responsible for autosomal recessive parkinsonism in Europe. French Parkinson's Disease Genetics Study Group and the European Consortium on Genetic Susceptibility in Parkinson's Disease. Hum Mol Genet 1999;8:567-74.

24 Lucking CB, Durr A, Bonifati V, Vaughan J, De Michele G, Gasser T, Harhangi BS, Meco G, Denefle P, Wood NW, Agid Y, Brice A. Association between early-onset Parkinson's disease and mutations in the parkin gene. French Parkinson's Disease Genetics Study Group. N Engl J Med 2000;342: 1560-7.

25 Periquet $M$, Lucking $C$, Vaughan J, Bonifati V, Durr A, De Michele G, Horstink M, Farrer M, Illarioshkin SN, Pollak P, Borg M, Brefel-Courbon C, Denefle P, Meco G, Gasser T, Breteler MM, Wood N, Agid Y, Brice A. Origin of the mutations in the parkin gene in Europe: exon rearrangements are independent recurrent events, whereas point mutations may result from founder effects. Am J Hum Genet 2001;68:617-26

26 Valente EM, Bentivoglio AR, Dixon PH, Ferraris A, lalongo T, Frontali $M$, Albanese A, Wood NW. Localization of a novel locus for autosomal recessive early-onset parkinsonism, PARK6, on human chromosome 1 p35-p36. Am J Hum Genet 2001;68:895-900.

27 van Duijn CM, Dekker MC, Bonifati V, Galjaard RJ, Houwing-Duistermaat JJ, Snijders PJ, Testers L, Breedveld GJ, Horstink M, Sandkuijl LA, van Swieten JC, Oostra BA, Heutink P. Park7, a novel locus for autosomal recessive early-onset parkinsonism, on chromosome $1 \mathrm{p} 36$. Am J Hum Genet 2001;69:629-34.

28 Lang AE, Fahn S. Assessment of Parkinson's disease. In: Munsat TL, ed. Quantification of neurologic deficit. Boston: Butterworth, 1989:285-309.

29 Hughes AJ, Ben Shlomo Y, Daniel SE, Lees AJ. What features improve the accuracy of clinical diagnosis in Parkinson's disease: a clinicopathologic study. Neurology 1992;42:1142-6.

30 Hughes AJ, Daniel SE, Kilford L, Lees AJ. Accuracy of clinical diagnosis of idiopathic Parkinson's disease: a clinico-pathological study of 100 cases. J Neurol Neurosurg Psychiatry 1992;55:181-4.

31 Machado RD, Pauciulo MW, Thomson JR, Lane KB, Morgan NV, Wheeler L, Phillips JA III, Newman J, Williams D, Galie N, Manes A, McNeil K, Yacoub M, Mikhail G, Rogers $P$, Corris $P$, Humbert M, Donnai D, Martensson G, Tranebjaerg L, Loyd JE, Trembath RC, Nichols WC. BMPR2 haploinsufficiency as the inherited molecular mechanism for primary pulmonary hypertension. Am J Hum Genet 2001;68:92-102.

32 O'Connell JR, Weeks DE. PedCheck: a program for identification of genotype incompatibilities in linkage analysis. Am J Hum Genet 1998;63:259-66

33 Goring $\mathbf{H H}, \mathrm{Ott} J$. Relationship estimation in affected sib pair analysis of late-onset diseases. Eur J Hum Genet 1997:5:69-77.

34 Kruglyak L, Lander ES. Complete multipoint sib-pair analysis of qualitative and quantitative traits. Am J Hum Genet 1995;57:439-54.

35 Gudbjartsson DF, Jonasson K, Frigge ML, Kong A. Allegro, a new computer program for multipoint linkage analysis. Nat Genet 2000;25:12-13.

36 Yau SC, Bobrow M, Mathew CG, Abbs SJ. Accurate diagnosis of carriers of deletions and duplications in Duchenne/Becker muscular dystrophy by fluorescent dosage analysis. J Med Genet 1996;33:550-8.

37 Farrer M, Chan P, Chen R, Tan L, Lincoln S, Hernandez D, Forno L, Gwinn-Hardy K, Petrucelli L, Hussey J, Singleton A, Tanner C, Hardy J, Langston JW. Lewy bodies and parkinsonism in families with parkin mutations. Ann Neurol 2001;50:293-300.

38 Dunnen JT, Antonarakis SE. Mutation nomenclature extensions and suggestions to describe complex mutations: a discussion. Hum Muta 2000;15:7-12. 